\title{
Young people's uncertainty about the future: Education system, training, and transition to employment in Spain
}

\author{
Roberto Moreno López, Beatriz Esteban Ramiro, and Rut Barranco Barroso*
}

doi: http://dx.doi.org/10.18543/tjhe-7(2)-2020pp67-89

Received: 9 October 2019

Accepted: 23 March 2020

\begin{abstract}
The general context of precariousness of employment affects youth in Spain. Delving deeper into the axes that traverse this uncertainty, we present part of a cross-sectional study on the perception of young people in the city of Toledo, in which an ad hoc questionnaire was used for data collection to compare the results at the Spanish and European level. The sample includes 505 people aged between 16 and 24 years. The main findings indicate a general dissatisfaction with the training received and a lack of adaptation of the transition system to the labor market, elements that repeat themselves in the perception of different agents regarding this context. Significant differences were found regarding the perception of problems considering the education level of the parents and aspects related to the autonomy of the young people, such as living independently or living off of their own income. This represents clear similarities with young Europeans and especially in the Spanish case but presents specific difficulties for young people in regions such as Castilla-La Mancha.
\end{abstract}

Keywords: Youth unemployment; inequality; educational system; labor market.

\section{Introduction}

According to data released by Eurostat in 2018, almost 17 million residents of the European Union (EU) were unemployed. One of the main

* Roberto Moreno López (roberto.moreno@uclm.es), Doctor in Humanities and Education, is an associate professor at the University of Castilla-La Mancha (UCLM), Spain, in the Department of Pedagogy.

Beatriz Esteban Ramiro (beatriz.esteban@uclm.es), a PhD student, is an associate professor at the University of Castilla-La Mancha (UCLM) in the Department of Labor Law and Social Work.

Rut Barranco Barroso (rut.barranco@uclm.es) is an associate professor in Social Education at the Social Sciences College of Talavera de la Reina at the University of Castilla- La Mancha (Spain).

More information about the author is available at the end of this article. 
objectives of the Europe 2020 strategy is for $75 \%$ of the active population (20-64 years) to have a job by the end of the decade. In particular, the EU works to reduce the youth unemployment rate, which is double that of adults. Young people generally face an increased risk of unemployment (in February 2019, the unemployment rate of 15 to 24-year-olds was more than double that for the entire population, $16.1 \%$ versus $7.8 \%$, respectively). For this reason, a more specific and holistic approach to fight against youth unemployment is encouraged. ${ }^{1}$ The strategic planning policies promoted by the EU reflect a more detailed and holistic approach to this issue, with direct support for the most needy youth, structural reform to strengthen partnerships between ministries, formal education systems, professional education agencies, employment agencies, and companies, social partners and civil society organizations from all countries of the EU. ${ }^{2}$

The economic crisis has deepened and highlighted the difficulty of young people identifying and securing a place in the labor market, given their high sensitivity to macroeconomic evolution, demonstrated empirically in the work of many researchers before the recession. ${ }^{3{ }^{3}}$ The impact of unemployment in periods of crisis, especially affects young people. This is a reality reflected historically. This situation of special vulnerability in work spaces results in a greater probability of being unemployed, underemployed or precarious, often tripling the unemployment rates of the general population. ${ }^{5}$ According to the United Nations Development Program ${ }^{6}$, they would be a group with special sensitivity to macroeconomic transformations and instabilities, as could have been verified in recent years by the consequences and effects of the economic crisis and the repeated and prolonged impacts, in this group,

${ }^{1}$ Eurostat Statistic Explained, https://ec.europa.eu/eurostat/statistics- explained/index. php?title=Employment_statistics/es, published in February, 2019.

${ }^{2}$ European Commission, "Employment and social developments in Europe" (Brussels: Directorate General for Employment, Social Affairs and Inclusion, 2013).

${ }^{3}$ David G. Blanchflower and Richard B. Freeman, Youth employment and joblessness in advanced countries (Chicago: University of Chicago Press, 2007).

${ }^{4}$ Juan F. Jimeno and Diego Rodriguez-Palenzuela, "Youth unemployment in the OECD: demographic shifts, labour market institutions, and macroeconomic shocks", Working Paper No. 155, European Central Bank,( June 2002), https://papers.ssrn.com/sol3/papers. cfm?abstract_id=357960.

5 Rubén Lasheras Ruiz and Begoña Pérez Eransus, "Jóvenes, vulnerabilidades y exclusión social: impacto de la crisis y debilidades del sistema de protección social," Revista de Servicios Sociales, 57 (2014): 137-157.

${ }^{6}$ United Nations Development Programme, "Youth Strategy 2014-2017” (2014), https:// www.undp.org/content/dam/undp/library/Democratic\%20Governance/Youth/UNDP_YouthStrategy-2014-17_Web.pdf. 
despite possible recoveries. Thus, a first conclusion of studies such as those of Marelli and Marcello ${ }^{7}$ is that the relative position of young people, compared to those in other countries in the area, is more adverse in two types of countries: countries where the majority of adverse economic conditions (both structural and cyclical), especially after the recent crisis, are reflected in high unemployment (such as Greece, Spain, Italy, etc.) and countries that, despite the generally better economic conditions, are characterized by institutional characteristics that are not particularly favorable for young people (such as Great Britain, Sweden, Belgium, Poland, etc.).

Throughout the last few decades, the dawn of postindustrial society based on knowledge has coincided with the growing complexity, difficulty and duration of the transition of young people from school to work. ${ }^{8}$ Despite high investments in education for younger generations, in almost all European countries, young people are more exposed to vulnerable living conditions and precarious positions in the labor market and have fewer opportunities compared to their parents. ${ }^{9}$

The analysis of institutional, structural, social and macroeconomic factors broadens the perspective in the exploration of the main elements that are intervening in excluding young people from the labor market, understanding that this exclusion no longer has an isolated character but has become a trend that does not revert even with the implementation of different strategies. ${ }^{10}{ }^{1}{ }_{11}, 12$ The situation in Spain is particularly worrying, which in the last decade has led to an increase in difficulties for young people accessing their first job. Youth unemployment was at 33.54 points in the fourth quarter of 2018. ${ }^{13}$ Youth development has been centered around two specific

${ }^{7}$ Enrico Marelli and Signorelli Marcello, "Young people in crisis times: Comparative evidence and policies," CESifo Forum.18. 2 (München: ifo Institut-Leibniz-Institut für Wirtschaftsforschung an der Universität München, 2017), 19-25.

${ }^{8}$ Hans Dietrich, "Youth unemployment in Europe," Theoretical considerations and empirical findings (2012), https://library.fes.de/pdf-files/id/ipa/09227.pdf.

9 Misbah Tanveer Choudhry et al., "Youth unemployment rate and impact of financial crises," International journal of manpower 33.1 (2012):76-95.

${ }^{10}$ Rubén Lasheras Ruiz and Begoña Pérez Eransus, "Jóvenes, vulnerabilidades y exclusión social: impacto de la crisis y debilidades del sistema de protección social," Revista de Servicios Sociales, 57 (2014): 137-157.

${ }^{11}$ Robert MacDonald, "Disconnected youth? Social exclusion, the 'underclass'\& economic marginality," Social Work \& Society 6.2 (2008): 236-248.

12 Stefano Scarpetta et al., "Rising youth unemployment during the crisis" (2010).

13 "INE. Instituto Nacional de Estadística", Encuesta de Población Activa (EPA), Cuarto trimestre 2019, INE, (published on February 28, 2020), https://www.ine.es/daco/daco42/ daco4211/epa0419.pdf. 
precepts related to training and job placement. The breakdown of these two elements in the labor market has accentuated the vulnerability of young people both in their personal and collective spheres. The current situation responds to a historic reality in Spain that is characterized by a labor market whose fabric is low-skilled labor, which favors temporary work and it is accompanied by deregulation. ${ }^{14}$ Young people are among the groups in which the highest rates of temporary work, precarity, fragmentation and underemployment are found. ${ }^{15,16,17}$ All of these factors have a significant impact on the autonomy and participation of young people. The high rates of youth unemployment are no longer explained by structural transformations and the divergence between the demand and supply of skills, competencies and aptitudes, as was noted in the last century. ${ }^{18,19}$

Despite the break in the direct relationship between training and job placement that occurred in other time periods, the specialized literature reflects that exposure to risks and the vulnerability of young people have strong relationships with their education level..$^{20,21,22}$ The level of education

${ }^{14}$ Jorge Benedicto et al., "Informe juventud en España 2016," (Madrid: Instituto de la Juventud, 2017).

${ }^{15}$ FOESSA, Fundación, VII Informe sobre exclusión social y desarrollo social en España (Madrid: Cáritas/Fundación FOESSA ,2014),cap. 3, https://www.foessa2014.es/informe/ uploaded/descargas/VII_INFORME.pdf.

${ }^{16}$ Marí Angels Cabasés i Piqué, et al., "El modelo de empleo juvenil en España (20132016)," Política y Sociedad 54, no. 3 (2017):733-755.

17 Joan Miquel Verd Pericàs et al., "Trayectorias laborales y capital social en la población joven: elementos para analizar la precariedad laboral juvenil más allá de los grandes focos," Anuario IET de trabajo y relaciones laborales 3 (2016): 144-158.

${ }^{18}$ Kim B. Clark and Lawrence H. Summers, "The Dynamics of Youth Unemployment," in The Youth Labour Market Problem: Its Nature, Causes, and Consequences. A National Bureau of Economics Research Conference Report, ed. Richard B. Freeman and David A. Wise (Chicago and London: The University of Chicago Press, 1982).

${ }^{19}$ David G Blanchflower and B. Richard Freeman, "The Declining Economic Status of Young Workers in OECD Countries," Youth Employment and Joblessness in Advanced Countries (2000): 19-56.

${ }^{20}$ Adoración Guamán Hernández, "De la estabilidad en el empleo a la precariedad laboral por la vía de la contratación temporal: la inserción de los jóvenes en el mercado de trabajo como paradigma del trabajo precario," Anuario de la Facultad de Derecho 6 (Universidad de Alcalá: 2013): 103-136, https://ebuah.uah.es/dspace/handle/10017/20089.

${ }^{21}$ María Angels Cabasés i Piqué et al., "Precariedad y temporalidad, principales características del empleo juvenil en España," Revista del Ministerio de Empleo y Seguridad Social, 126 (2016): 31-52.

${ }^{22}$ Rubén Lasheras Ruiz and Begoña Pérez Eransus, "Jóvenes, vulnerabilidades y exclusión social: impacto de la crisis y debilidades del sistema de protección social," Revista de Servicios Sociales 57 (2014): 137-157. 
continues to be the most predictive factor for the evolution of people in the youth labor market. ${ }^{23}$ Eurostat indicates that the proportion of poorly qualified young people represented $70 \%$ of the population of not in employment, education, or training (NEET) in countries such as Spain and Portugal while exceeding $50 \%$ in other countries such as Holland, Denmark, Germany, Bulgaria, Austria, Romania and Italy.$^{24}$ However, it must be taken into account that less qualified workers will be more affected by the crisis. In the Spanish case, the employment rates of university students have been and are higher than those of those with a lower education level, such that in the middle ages of life, the employment rate reaches approximately $95 \%$, while in the older generations, the rate is practically $100 \%$. However, in the case of university graduates in the process of labor integration, in the current recession, employment rates are lower than those reached by previous generations of university students of the same age..$^{25}$

Today, educational policies significantly influence the tomorrow social policy. In this sense, research within universities aims to "discover new scientific, artistic and technological knowledge, to ensure the development of society". ${ }^{26}$ Well-educated people have better opportunities in the labor market, are less frequently unemployed, tend to be more satisfied with their job and, because they earn more, pay higher taxes and contributions to Social Security. ${ }^{27}$ In recent years, the rate of early dropout has been reduced to $17.9 \%$. The European average was $10.6 \%$, while in Spain, the rate is much higher, $18.3 \% .^{28}$

Given this situation, it is necessary to continue deepening the knowledge of situations that especially affect young people in the Spanish territory.

${ }^{23}$ Hans Dietrich, "Youth unemployment in Europe," Theoretical considerations and empirical findings (February 2012), https://library.fes.de/pdf-files/id/ipa/09227.pdf.

${ }^{24}$ Valentina Vasile and Irina Anghel. "The educational level as a risk factor for youth exclusion from the labour market," Procedia Economics and Finance 22 (2015): 64-71.

${ }^{25}$ FOESSA, Fundación, VII Informe sobre exclusión social y desarrollo social en España (Madrid: Cáritas/Fundación FOESSA ,2014), cap. 3, https://www.foessa2014.es/informe/ uploaded/descargas/VII_INFORME.pdf.

26 Alex Estrada García,"Estilos de aprendizaje y rendimiento académico,", Revista Boletín Redipe , no.7.7 (2018):218-228.

27 O. E. C. D, Indicators, Education at a Glance 2016, (Paris: OECD Publishing, 2016), https://doi.org/10.1787/eag-2016-en.

${ }^{28}$ Ministerio de Educación, Cultura y Deporte, Sistema Estatal de Indicadores de la Educación 2017, (Madrid: Secretaría General Técnica. Centro de Publicaciones, 2017), https:// sede.educacion.gob.es/publiventa/sistema-estatal-de-indicadores-de-la-educacionedicion-2017/educacion-espana/22080. 
Delving deeper into the perceptions and knowledge of their life experiences is a necessity for the development of actions from a social and educational perspective that helps improve their situation as a group. In this way, he proposes a perception study to understand the main concerns and situations of young people in the city of Toledo, which, along with other elements, can be an instrument of orientation for the design of local public policies aimed at young people and therefore of effective transition to employment programs.

\section{Method}

The main objective of the present study was to analyze the perception of young people in the city about their own situation. It was therefore intended to investigate the view of young people regarding their situations and to know what factors they identify as major problems and concerns. The study was carried out with a questionnaire prepared ad-hoc and administered in a survey process in schools and at street level through interviewers.

\section{II.1. Sample}

Representative sampling stratified by quotas in the nonschool population and by multieducational clusters was performed in the case of school environments. The conglomerates were established from educational centers and nonformal education entities. Stratified sampling by course and gender quotas was performed within each center. In the case of the nonschool population, the questionnaire was conducted on the street with sampling points in high population densities. A sampling error of $4.2 \%$ was applied with a $95 \%$ confidence interval, resulting in $\mathrm{N}=505$.

Stratification was performed by age, gender and professional situation: studying; working; and neither studying nor working. The sample comprised 505 young people between 16 and 24 years of age from the city of Toledo, of which 219 were men and 286 were women (43.4\% and 56.6\%, respectively). The age distribution was 15 to 17 years (186 cases, 36.9\%), 18 to 21 years (191 cases, 37.9\%), and 22 to 24 years (128 cases, 25.2\%). In the stratification by professional situation, the percentages of young people currently studying, working, or neither studying nor working were $61.74 \%, 14.60 \%$ and $23.66 \%$, respectively. 


\section{Table 1}

Distribution of the sample according to education level

\begin{tabular}{|c|c|c|c|}
\hline & $\begin{array}{c}\text { Level of } \\
\text { education of the } \\
\text { father }\end{array}$ & $\begin{array}{l}\text { Level of } \\
\text { education of the } \\
\text { mother }\end{array}$ & $\begin{array}{l}\text { Level of } \\
\text { education of the } \\
\text { young person }\end{array}$ \\
\hline & $\begin{array}{l}\% \text { of the } \mathrm{N} \text { in } \\
\text { the table }\end{array}$ & $\begin{array}{l}\% \text { of the } \mathrm{N} \text { in } \\
\text { the table }\end{array}$ & $\begin{array}{l}\% \text { of the } \mathrm{N} \text { in } \\
\text { the table }\end{array}$ \\
\hline $\begin{array}{l}\text { I have not completed } \\
\text { compulsory education }\end{array}$ & $10.5 \%$ & $7.7 \%$ & $9.6 \%$ \\
\hline Compulsory education & $14.9 \%$ & $16.1 \%$ & $2.2 \%$ \\
\hline ESO & $18.8 \%$ & $20.1 \%$ & $23.3 \%$ \\
\hline Baccalaureate & $13.0 \%$ & $10.8 \%$ & $20.7 \%$ \\
\hline Vocational training & $18.6 \%$ & $18.1 \%$ & $14.3 \%$ \\
\hline University studies & $18.0 \%$ & $21.3 \%$ & $28.1 \%$ \\
\hline Postgraduate or master's & $3.3 \%$ & $5.3 \%$ & $0.2 \%$ \\
\hline Doctorate & $2.7 \%$ & $0.4 \%$ & $0.2 \%$ \\
\hline NA & $0.2 \%$ & $0.2 \%$ & $1.4 \%$ \\
\hline
\end{tabular}

Source: the authors

\section{II.2. Instrument}

The instrument for gathering information was an ad hoc questionnaire with a total of 38 questions with Likert type scale the following dimensions and variables: sociodemographic, general state of youth and lifestyle; attitude; social networks; problems of young people; attitudes toward gender-based violence, school bullying and cyber bullying; information and drug consumption; youth unemployment and job placement expectations; participation in organizations; and knowledge and assessment activities of the local youth council.

\section{II.3. Procedure}

Given the characteristics of the school population and the non-school population, it was necessary to develop and design an information collection procedure in two systems: 
- Educational center: self-administered questionnaire in the presence of interviewers during the entire completion of the questionnaire. The interviewers completed the introduction and the instructions for completing the questionnaire, emphasizing the most complex questions or those with a filter question. Education centers: secondary education institutes/universities, 342 questionnaires (68\% of the sample).

- Street: the questionnaire was completed with an interviewer in areas with a high concentration of young people, such as university environments, sports centers and leisure areas. Street: 163 questionnaires (32\%).

Data collection was performed during the months of May and June 2016. Regarding the analysis procedure, descriptive data mining was performed with the SPSS Statistics 22 program from frequency tables and crosstabulations. From them, Pearson $r$ correlation matrices and an analysis of differences in means for the main dimensions of the questionnaire were developed.

\section{Results}

Below, we present the data relative to the main self-perceived problems of young people and how they measure each of them, in the general context of youth. This article presents the results of those that make direct reference to perceptions about the education and training situation and access to employment. In addition, a correlation analysis of different sociodemographic variables is performed with each of the main concerns reported by young people. To this analysis is added the configuration of two groups of analysis: the education level reached by young people and their situation regarding autonomy or dependence on the family home. Additionally, the education levels of the parents are analyzed.

Beginning with the analysis of the results, the view that young people have about the adequacy of the educational system and curricula to the labor market is one of the main perceived problems. A significant number of young people think the curricula pose a problem in motivation for learning and in providing a good educational foundation for entry into the labor market. The highest frequency scores reported for this concern are 7-10. Thus, grouping the scores of this interval, 55.1\% indicate concern in this regard. Another problem of concern is the lack of interest in studying, which translates into 
significant dropout rates and academic failure. For the young people in this study, 51.5\% indicate a concern between $7-10$, and more than half of the sample reports this as a very important concern.

For the problem of uncertainty about the future of young people, the highest frequency score $(21.6 \%)$ is the maximum score according to degree of importance, which is 10 . Of these, $64.2 \%$ indicate that this as a very important problem. This is, therefore, one of the concerns that is clearly related to unemployment. Difficulties in leaving the family home also continues to be one of the most challenging problems for young people today. The highest frequency score, $16.4 \%$, is the maximum score for level of concern. A total of $61.5 \%$ of the sample reported a level of concern between 7 and 10 .

The majority of young people indicate that it is very important to address quality of employment. This element is especially important because precarity is one of the main characteristics of youth employment. Young people, as noted in the introduction, are affected by a segregated labor market that influences the quality of their jobs. Most of the young people surveyed scored this issue with a level of importance between 5 and 10, representing $79.2 \%$.

Another relevant issue is economic problems; $74.4 \%$ rated this problem as more than 6 , indicating that this issue is very important to young people. We can establish a certain relationship between situation of unemployment or difficulties with employment with the economic situation that follows.

To conclude the first part of the descriptive analysis regarding the main problems described by young people as very important, unemployment is presented as a perceived fundamental problem, with $70 \%$ providing scores between 7-10 for the level of importance for the problem of unemployment. That is, the perception of the importance of the problem of unemployment among the young population is a primary element, in accordance with the reality that this group lives.

The analysis reflected below shows the differences in perception regarding the general problems that affect young people, discerning between the perception of themselves and the perception of youth in general. A comparison of average scores is shown. In order of relevance in terms of identifying the problems that affect young people in general, unemployment and uncertainty about the future are the two elements that are most concerning to those surveyed. In terms of self-perception of self-problems, uncertainty of the future and the educational system and curricula have the highest scores; these are the most relevant problems reported, followed by unemployment, as shown in Table 2. 
Table 2

Comparison of means for the perception of problems

\begin{tabular}{|l|c|c|}
\hline & $\begin{array}{c}\text { Problems of } \\
\text { young people }\end{array}$ & $\begin{array}{c}\text { Personal } \\
\text { problems }\end{array}$ \\
\hline Unemployment & 7.41 & 7.70 \\
\hline Economic problems & 7.09 & 7.00 \\
\hline Quality of employment & 6.70 & 7.12 \\
\hline Difficulty leaving home, lack of support & 6.88 & 6.66 \\
\hline Uncertainty about the future & 7.09 & 8.05 \\
\hline Lack of interest in studies & 6.37 & 6.80 \\
\hline Educational system, curricula & 6.71 & 7.81 \\
\hline
\end{tabular}

Source: the authors

For the following analysis, a comparison of Student's t-test means is performed, as well as a correlational analysis between different variables and perception of the problems. Following the main positions presented in the introduction, it is hypothesized that the perception of young people regarding the problems they consider important are affected by different factors that generally relate to protective or risk factors in their socioeconomic situation and closely relate to their levels of autonomy. Thus, to perform these tests, the following variables were taken into account in comparative and correlational perspectives: education level attained, education level of the parents, education level of the mother, place of residence (if residing with the parents or independently) and origin of income (own or from other people). The main hypotheses therefore indicate that education level, both of one's own and that of the parents, minimizes perceived risk to certain problems. However, depending on the place of residence and therefore on the autonomy of young people, some more relevant problems will be placed over others. Thus, problems related to the economic situation and unemployment will be more worrisome to people who live independently, due to the risks of not having economic/monetary and employment needs covered to maintain their autonomy; young people who live with their parents will be more concerned about problems related to the educational system because, to a greater extent, they remain in it, and perception of problems related to leaving home will be more significant because this situation has not occurred. 
Table 3

T-test. Differences in the perception of problems according to place of residence

\begin{tabular}{|l|l|l|l|c|c|c|c|}
\hline & $\begin{array}{c}\text { Place of } \\
\text { residence }\end{array}$ & $\mathrm{N}$ & Mean & $\begin{array}{c}\text { Standard } \\
\text { deviation }\end{array}$ & $\mathrm{t}$ & $\begin{array}{c}\text { Sig. } \\
\text { (bilateral) }\end{array}$ & $\begin{array}{c}\text { Dif. } \\
\text { means }\end{array}$ \\
\hline Unemployment & $\begin{array}{l}\text { In the home } \\
\text { of the family } \\
\text { of origin } \\
\text { with one or } \\
\text { both parents }\end{array}$ & 328 & 7.52 & 3.208 & -1.983 & .048 & -1.206 \\
\hline $\begin{array}{l}\text { A home of } \\
\text { their own } \\
\text { independent } \\
\text { of the family } \\
\text { of origin }\end{array}$ & 29 & 8.72 & 2.170 & -2.740 & .009 & -1.206 \\
\hline $\begin{array}{l}\text { Quality of } \\
\text { employment }\end{array}$ & $\begin{array}{l}\text { In the home } \\
\text { of the family } \\
\text { of origin } \\
\text { with one or } \\
\text { both parents }\end{array}$ & 323 & 6.94 & 3.203 & -2.086 & .038 & -1.318 \\
\hline & $\begin{array}{l}\text { A home of } \\
\text { their own } \\
\text { independent } \\
\text { of the family } \\
\text { of origin }\end{array}$ & 27 & 8.26 & 2.474 & -2.592 & .014 & -1.318 \\
\hline
\end{tabular}

Source: the authors

As detailed in Table 3, the comparison of mean differences between those living with parents and those living alone shows significant differences, on the one hand, regarding the perception of the unemployment problem, with a difference of -1.206 and a significance of .009 . That is, unemployment is a problem that concerns young people who have left home (8.72 average) more so than those who still live with their parents (7.52). On the other hand, on the perception of quality of employment, a value of -1.318 was obtained, with a significance of .014 .

Taking into account the usual source of income for living, the variables that are significantly different are the difficulty leaving home and access to support, with a difference of means of -.994 and a significance level of .004, which implies that young people who live off of the income of other people are less concerned about these issues than those who live off of their own income. Although this result may be paradoxical, with the understanding that 
people who have not yet left home could be more concerned about that issue, this result could be due, as noted above, to difficulties experienced in leaving home and lack of support in this sense, which is different from those who have already done so, as well as to difficulties of sustaining a household.

Table 4

T-test. Differences in the perception of problems according to income origin

\begin{tabular}{|l|l|c|c|c|c|c|c|}
\hline & $\begin{array}{l}\text { Personal } \\
\text { economic } \\
\text { situation }\end{array}$ & $\mathrm{N}$ & Mean & $\begin{array}{c}\text { Standard } \\
\text { deviation }\end{array}$ & $\mathrm{t}$ & $\begin{array}{c}\text { Sig. } \\
\text { (bilateral) }\end{array}$ & $\begin{array}{c}\text { Dif. } \\
\text { means }\end{array}$ \\
\hline $\begin{array}{l}\text { Difficulty } \\
\text { in leaving } \\
\text { home, lack } \\
\text { of support }\end{array}$ & $\begin{array}{l}\text { Income } \\
\text { from other } \\
\text { people }\end{array}$ & 350 & 6.60 & 3.020 & -2.802 & .005 & -.994 \\
\cline { 2 - 8 } & $\begin{array}{l}\text { Own } \\
\text { income }\end{array}$ & 88 & 7.59 & 2.782 & -2.943 & .004 & -.994 \\
\hline $\begin{array}{l}\text { Educational } \\
\text { system, } \\
\text { curricula }\end{array}$ & $\begin{array}{l}\text { Income } \\
\text { from other } \\
\text { people }\end{array}$ & 355 & 7.97 & 2.276 & 2.666 & .008 & .770 \\
\cline { 2 - 8 } & $\begin{array}{l}\text { Own } \\
\text { income }\end{array}$ & 89 & 7.20 & 2.989 & 2.269 & .025 & .770 \\
\hline
\end{tabular}

Source: the authors

For the variables that present a statistically representative difference, youth who live on other people's income are more concerned about problems related to the educational system and curricula, reporting a mean difference of .770 with a significance level of .008 . In this case, this result is observed because the vast majority of young people who study or have an interest in continuing to do so live in the family home and/or depend on their own income (Table 4)

Table 5 shows the correlational analysis taking into account, as variables, whether there is any relationship between education level (one's own and, especially, the education level of the parent) and the perception of personal problems, which in general correlate inversely with the education levels of the parents. That is, there is a greater perception of problems by young people when parents have lower education levels. This is reflected, for example, in difficulties leaving home; lower education levels of the father and the mother (Pearson correlation, -.228 with a significance of .00) result in greater concern. Regarding concern about unemployment, a lower education level of the father results in greater 
Table 5

Correlations of personal problems and one's own education level and that of the parents

\begin{tabular}{|c|c|c|c|c|}
\hline \multicolumn{2}{|c|}{ Personal problems } & \multirow{2}{*}{$\begin{array}{c}\begin{array}{c}\text { Level of } \\
\text { studies } \\
\text { completed }\end{array} \\
.223^{* *}\end{array}$} & \multirow{2}{*}{$\begin{array}{c}\begin{array}{c}\text { Education } \\
\text { level of the } \\
\text { father }\end{array} \\
-.181^{* *}\end{array}$} & \multirow{2}{*}{$\begin{array}{c}\begin{array}{c}\text { Education } \\
\text { level of the } \\
\text { mother }\end{array} \\
-.152^{* *}\end{array}$} \\
\hline Unemployment & Pearson correlation & & & \\
\hline & Sig. (bilateral) & .000 & .000 & .001 \\
\hline & $\mathrm{N}$ & 487 & 474 & 482 \\
\hline \multirow[t]{3}{*}{ Economic problems } & Pearson correlation & $.129^{* *}$ & $-.126^{* *}$ & $-.161^{* *}$ \\
\hline & Sig. (bilateral) & .004 & .006 & .000 \\
\hline & $\mathrm{N}$ & 486 & 474 & 482 \\
\hline \multirow{3}{*}{$\begin{array}{l}\text { Quality of } \\
\text { employment }\end{array}$} & Pearson correlation & $.187^{* *}$ & $-.105^{*}$ & $-.143^{\star *}$ \\
\hline & Sig. (bilateral) & .000 & .023 & .002 \\
\hline & $\mathrm{N}$ & 479 & 466 & 474 \\
\hline \multirow{3}{*}{$\begin{array}{l}\text { Difficulty leaving } \\
\text { home, lack of } \\
\text { support }\end{array}$} & Pearson correlation & $.171^{* *}$ & $-.131^{* *}$ & $-.228^{* *}$ \\
\hline & Sig. (bilateral) & .000 & .004 & .000 \\
\hline & $\mathrm{N}$ & 481 & 469 & 476 \\
\hline \multirow{3}{*}{$\begin{array}{l}\text { Uncertainty about } \\
\text { the future }\end{array}$} & Pearson correlation & $.117^{* *}$ & $-.119^{* *}$ & $-.148^{* *}$ \\
\hline & Sig. (bilateral) & .010 & .009 & .001 \\
\hline & $\mathrm{N}$ & 487 & 473 & 481 \\
\hline \multirow{3}{*}{$\begin{array}{l}\text { Lack of cultural } \\
\text { activities, lack of } \\
\text { leisure spaces }\end{array}$} & Pearson correlation & $.091^{*}$ & -.084 & $-.109^{*}$ \\
\hline & Sig. (bilateral) & .046 & .069 & .017 \\
\hline & $\mathrm{N}$ & 481 & 468 & 476 \\
\hline \multirow{3}{*}{$\begin{array}{l}\text { Lack of interest in } \\
\text { studying }\end{array}$} & Pearson correlation & .053 & -.062 & $-.096^{*}$ \\
\hline & Sig. (bilateral) & .240 & .180 & .036 \\
\hline & $\mathrm{N}$ & 486 & 473 & 481 \\
\hline \multirow{3}{*}{$\begin{array}{l}\text { Education level of } \\
\text { the father }\end{array}$} & Pearson correlation & -.018 & 1 & $.594^{\star *}$ \\
\hline & Sig. (bilateral) & .697 & & .000 \\
\hline & $\mathrm{N}$ & 474 & 483 & 480 \\
\hline \multirow{3}{*}{$\begin{array}{l}\text { Education level of } \\
\text { the mother }\end{array}$} & Pearson correlation & .008 & $.594^{\star \star}$ & 1 \\
\hline & Sig. (bilateral) & .855 & .000 & \\
\hline & $\mathrm{N}$ & 482 & 480 & 491 \\
\hline
\end{tabular}

Source: the authors 
concern by young people, with a Pearson correlation of - .181 and a significance level of .00 .

An important piece of information that appears in the correlation analysis and that may be related to the configuration of households as a function of education level is the strong correlation between levels of education of the mother and those of the father, represented by a Pearson coefficient of .594 and a significance of .00 . The higher the maternal education level is, the higher the education level of the father. That is, a high education level reported for the mothers indicates a high education level for both the parents. To analyze how paternal educational training acts as a factor on the perception of problems by young people, a new analysis of the differences of means using T-tests is conducted. Education levels are grouped as follows: completed higher education or no education.

\section{Table 6}

T-tests of the education level of fathers and perceived personal problems by young people

\begin{tabular}{|l|l|c|c|c|c|c|}
\hline & $\begin{array}{l}\text { Education } \\
\text { level of the } \\
\text { father }\end{array}$ & $\mathrm{N}$ & Mean & $\begin{array}{c}\text { Standard } \\
\text { deviation }\end{array}$ & $\begin{array}{c}\text { Sig. } \\
\text { (bilateral) }\end{array}$ & $\begin{array}{c}\text { Difference } \\
\text { in means }\end{array}$ \\
\hline Unemployment & $\begin{array}{l}\text { Higher } \\
\text { education }\end{array}$ & 112 & 6.85 & 3.291 & .000 & -1.166 \\
\cline { 2 - 7 } & $\begin{array}{l}\text { Higher } \\
\text { education }\end{array}$ & 362 & 8.01 & 2.713 & .001 & -1.166 \\
\hline $\begin{array}{l}\text { Economic } \\
\text { problems }\end{array}$ & $\begin{array}{l}\text { Higher } \\
\text { education }\end{array}$ & 113 & 6.33 & 3.107 & .007 & -.897 \\
\cline { 2 - 7 } & $\begin{array}{l}\text { Higher } \\
\text { education }\end{array}$ & 361 & 7.22 & 3.056 & .008 & -.897 \\
\hline $\begin{array}{l}\text { Difficulty in } \\
\text { leaving home, } \\
\text { lack of support }\end{array}$ & $\begin{array}{l}\text { Higher } \\
\text { education }\end{array}$ & 113 & 6.15 & 3.194 & .026 & -.729 \\
\cline { 2 - 7 } & $\begin{array}{l}\text { Higher } \\
\text { education }\end{array}$ & 356 & 6.88 & 2.963 & .033 & -.729 \\
\hline $\begin{array}{l}\text { Uncertainty } \\
\text { about the } \\
\text { future }\end{array}$ & $\begin{array}{l}\text { Higher } \\
\text { education }\end{array}$ & 115 & 7.61 & 2.487 & .007 & -.651 \\
\cline { 2 - 7 } & $\begin{array}{l}\text { Higher } \\
\text { education }\end{array}$ & 358 & 8.26 & 2.175 & .013 & -.651 \\
\hline
\end{tabular}

Source: the authors 
Again, statistically significant differences are verified in those variables that relate to economic and employment situations; therefore, young people who perceive these problems with greater concern are those whose parents have lower education levels. This difference in means is reflected, as we see in Tables 6 and 7, in problems related to unemployment (-1.669), economic difficulties (-.897), difficulties in leaving home and access to support (-.729) and uncertainty about the future (-.651).

\section{Table 7}

T-tests of the education level of mothers and perceived personal problems by young people

\begin{tabular}{|l|l|c|c|c|c|c|}
\hline & $\begin{array}{l}\text { Education } \\
\text { level of the } \\
\text { mother }\end{array}$ & $\mathrm{N}$ & Mean & $\begin{array}{c}\text { Standard } \\
\text { deviation }\end{array}$ & $\begin{array}{c}\text { Sig. } \\
\text { (bilateral) }\end{array}$ & $\begin{array}{c}\text { Difference } \\
\text { in means }\end{array}$ \\
\hline Unemployment & $\begin{array}{l}\text { Higher } \\
\text { education }\end{array}$ & 129 & 7.11 & 3.085 & .009 & -.784 \\
\cline { 2 - 7 } & $\begin{array}{l}\text { Higher } \\
\text { education }\end{array}$ & 353 & 7.89 & 2.856 & .013 & -.784 \\
\hline $\begin{array}{l}\text { Economic } \\
\text { problems }\end{array}$ & $\begin{array}{l}\text { Higher } \\
\text { education }\end{array}$ & 130 & 6.48 & 3.063 & .028 & -.694 \\
\cline { 2 - 7 } & $\begin{array}{l}\text { Higher } \\
\text { education }\end{array}$ & 352 & 7.17 & 3.078 & .029 & -.694 \\
\hline $\begin{array}{l}\text { Difficulty in } \\
\text { leaving home, } \\
\text { lack of support }\end{array}$ & $\begin{array}{l}\text { Higher } \\
\text { education }\end{array}$ & 128 & 5.67 & 3.092 & .000 & -1.328 \\
\cline { 2 - 7 } & $\begin{array}{l}\text { Higher } \\
\text { education }\end{array}$ & 348 & 7.00 & 2.965 & .000 & -1.328 \\
\hline $\begin{array}{l}\text { Uncertainty } \\
\text { about the } \\
\text { future }\end{array}$ & $\begin{array}{l}\text { Higher } \\
\text { education }\end{array}$ & 131 & 7.63 & 2.576 & .012 & -.588 \\
\cline { 2 - 7 } & $\begin{array}{l}\text { Higher } \\
\text { education }\end{array}$ & 350 & 8.21 & 2.155 & .021 & -.588 \\
\hline
\end{tabular}

Source: the authors.

\section{Conclusions}

When analyzing the problems of young people, the main concern is unemployment and the problems arising from it, which generates great 
uncertainty about the future. However, the education level of parents can minimize the perceived risk of certain problems. This confirms the wellknown theory of Bourdieu, ${ }^{29}$ on the relationship between cultural capital and academic and labor outcomes. Furthermore, the vast majority of young people who study or have an interest in continuing to do so live in the family home and/or depend on their parent's income. Notably, young people who live off of other people's income are more concerned with problems related to the educational system and curricula. As reflected in the specialized literature, training, especially at higher levels, generally acts as a protective factor against the main risks and, more specifically, the perception of these risks. As noted in the document Youth, Inequalities and Social Exclusion by the Foessa Foundation, ${ }^{30}$ among others, one of the greatest factors of vulnerability for young people is coming from background of families in situations of social exclusion; hence relating this variable with education levels could respond this phenomenon.

Problems related to the economic situation and unemployment are more worrisome to people who live independently, due to the risk of not having sufficient economic and employment needs met, while young people who live with their parents are more concerned with the problems related to the educational system because, for the most part, they are still in school, and with perceived problems related to leaving home because this situation has not yet occurred.

Studies such as those by Meltze, Muir and Craig, ${ }^{31}$ found that trusted adults have more influence on the circumstances of young people and their future trajectories. This perspective provides a new picture of how the consequences of a relationship vary according to the level of commitment/ risk of the young people. This suggests that while it is potentially important for all young people, adult relationships of trust play a particularly important role for young people who are at risk of becoming disconnected or who are already disconnected and who lack other support. For successful training actions that improve employment rates of young people, a framework of complex relationships is needed that commits to coresponsibility and

${ }^{29}$ Pierre Bourdieu and J. C. Passeron, "La distinction, critique sociale du jugement," (Paris: Éditions de Minuit, 1979).

${ }^{30}$ FOESSA, Fundación, VII Informe sobre exclusión social y desarrollo social en España (Madrid: Cáritas/Fundación FOESSA ,2014), chapt. 3, https://www.foessa2014.es/informe/ uploaded/descargas/VII_INFORME.pdf.

31 Ariella Meltzer, Kristy Muir, and Lyn Craig, "The role of trusted adults in young people's social and economic lives," Youth \& Society 50, no. 5 (2018): 575-592. 
coleadership of all educational agents, as noted by Longás and Riera ${ }^{32}$ This leads to relying on new educational policies that promote equity and inclusion, not only focusing on when to intervene but also on how and where. ${ }^{33}$ The lack of availability of jobs due to structural change and the economic crisis is undoubtedly one of the reasons why young people are not employed in many countries. ${ }^{34}$

Within this process, a significant number of young people have been excluded from the labor market and the education system, commonly known as jóvenes neet (from the Spanish nini=ni estudia, ni trabaja, neither studies nor works), and this group has become a priority of employment and educational policies developed in recent years in Spain and in Europe. ${ }^{35}$ The demands of companies are concentrated in two broad categories: specific knowledge, which is the theoretical knowledge related to the training received and the functions that the individual will have to develop in the professional field; and experience/internships as an element of prior contact with the working world, whether or not it is related to the nature of the training received and cross-training competencies, understood as the skills or abilities developed by the individual independently of their theoretical training, applicable to any stage of life.$^{36}$ Therefore, when we speak of youth, it is necessary to take into account the transition from school to the labor market, where access to work and the creation of a home of one's own will correctly mark the transition to adult life. ${ }^{37}$ The most influential factors in the lives of young people are the family, which is considered the nucleus to meet

32 Jordi Longás and Jordi Riera. "Fracaso escolar y tránsito de los jóvenes hacia la vida adulta. Razones y propuestas para apoyar la transición de la escuela al trabajo," Educación Social, no. 49 (2007): 145-160.

33 Jordi Longás Mayayo, et al. "Análisis de factores de apoyo a trayectorias de éxito escolar en la enseñanza secundaria en contextos de pobreza y vulnerabilidad social en España. Un estudio de casos múltiples." REXE. Revista de Estudios y Experiencias en Educación, no.15:28 (2016): 107-127.

${ }^{34}$ Roberto Moreno López, Rosa Marí Ytarte and Beatriz Esteban Ramiro. "Labour market, education and the specific youth programs: study of perception in Toledo-Spain." International Journal of Adolescence and Youth,25:1 (2019): 1-17.

${ }^{35}$ Secretaria de Trabajo, Migraciones y Seguridad Social . [Ministry of Labour, Migrations and Social Security]. "Informe jóvenes y mercado de trabajo junio-2018". ihttp://www. mitramiss.gob.es/es/sec_trabajo/analisis-mercado trabajo/jovenes/numeros/2018/junio_2018. pdf

36 en el Empleo, Observatorio de Innovación. "Informe EOI sobre jóvenes y mercado laboral: El camino del aula a la empresa." (2014) .

37 Juan García-Fuentes, "Exclusión socio-educativa de los ni-ni: análisis descriptivo de los procesos de transición.” Revista Internacional de Didáctica y Organización Educativa 2.1 (2017). 
the needs and provide the necessary support during the childhood and youth stages ${ }^{38}$ which influences the school and work trajectories of their sons and daughters; the educational system, which poses some questions based on the existing processes of educational exclusion and the way of combating those processes; ${ }^{39}$ and the labor market, which is the goal of a transition marked by the end of academic studies and that provides important economic support for the individual..$^{40}$ Not possessing competencies is a substantial difficulty when entering the labor force, placing young people who do not acquire skills at high risk of exclusion and social vulnerability. ${ }_{41}{ }^{4},{ }_{43},{ }_{44}$ However, perhaps the response should not only result from introducing pedagogical innovations and/or improvements in the academic curriculum but also by considering and addressing other problems that exert a positive modulating effect on the education of young people. In this sense, we focus on support programs for the transition and pedagogical accompaniment framed in social education..$^{45}$

In this context and considering the perceptions of young people in their local environments, it is considered essential to contextualize these in the proposal by Planas ${ }^{46}$ conceiving that all possible actions should be integrated taking into account that there are three types of institutions that mainly intervene in the relationship between education and employment: first, education and professional training systems; second, companies in the broadest sense; and third, interface institutions that intervene in the regulation of the labor market. However, in addition, the space occupied by formal

38 Aina Tarabini-Castellani Clemente, “¿Qué se esconde bajo las apariencias?,”Cuadernos de pedagogía, 454 (2015):42-43.

39 Juan María Escudero et al., "Estudiantes en riesgo, centros escolares de riesgo: Respuestas educativas al alumnado en situaciones de vulnerabilidad," Murcia: DM (2013).

${ }^{40}$ Ulrich Beck, "La sociedad del riesgo. Hacia una nueva modernidad", Editorial PAIDOS. Buenos Aires-Argentina (1998).

${ }^{41}$ Anna Jolonch, "Exclusió social: dels marges al cor de la societat", Fundació Lluís Carulla (2008).

${ }^{42}$ Sebastián Sarasa and Albert Sales, "Itinerarios y factores de exclusión social", Fundación La Caixa (Barcelona, 2009).

${ }^{43}$ Cristina Boada et al., "Informe sobre el risc de fracàs escolar a Catalunya", Generalitat de Catalunya. Consell de Treball, Econòmic i Social de Catalunya, Collecció Estudis i Informes 26 (Barcelona, 2011).

44 Javier Gil Flores, "Hábitos lectores y competencias básicas en el alumnado de educación secundaria obligatoria." Educación XXI, 14.1 (2011), 117-134.

${ }^{45}$ Roberto Moreno López, "Formación e inserción sociolaboral en Educación Social", Vol. 27. Nau Llibres, (2018).

46 Jordi Planas Coll, "La relación entre educación y empleo en Europa," Revista de Sociologia 96.4 (2011):1047-1073. 
initial training in the process of acquiring skills and the weight of academic titles, although it continues to be determinant, decreases in favor of nonformal and informal processes that occur throughout the course of life. Therefore, the present study brings us closer to the precepts presented by Esteban and Sáe $\mathrm{z}^{47}$ that training, in a university or outside of it, is convened. If it is necessary to train, it is necessary to keep in mind who should be trained, for what and where. If people need to be qualified, i.e., future professionals, for certain types of work activities, one must not only think about appropriate training and how the training should mimic the reality of day-to-day employment but also of incorporation into culture, to the current-day scenarios professionals face.

There are certain limitations of the study of respect for the sample, since this study, although representative for the city of Toledo should not be taken to extrapolate the results in a literal way for other contexts. It should be cautious to take the associated results to combine with other studies in the same direction. This study offers us results that approximate us in the appropriate direction for decision making at the local level for the development of educational, training and employment-oriented actions in youth that promotes the most specialized way of supporting young people. Future studies would have to deepen the perception of trainers, specifically and business as a whole on these same problems studied.

\section{Bibliography}

Beck, Ulrich. "La sociedad del riesgo. Hacia una nueva modernidad.” Buenos Aires, Argentina: Editorial PAIDOS, 1998.

Benedicto, Jorge, Antonio Echaves, Teresa Jurado, María Ramos, and Benjamin Tejerina. "Informe juventud en España 2016." Madrid: Instituto de la Juventud, 2017.

Boada, Cristina, Diego Herrera, Eva Mas, Eva Miñarro, Marta Olivella, Xavier Riudor, Jorge Calero, Álvaro Choi and Josep Oriol Escardibul. "Informe sobre el risc de fracàs escolar a Catalunya." Collecció Estudis i Informes 26. Barcelona: Generalitat de Catalunya, Consell de Treball, Econòmic i Social de Catalunya, 2011.

Bourdieu, Pierre and J. C. Passeron. «La distinction, critique sociale du jugement.» Paris: Editions de Minuit, 1979.

${ }^{47}$ Manuel Esteban and Juan Sáez, "Las profesiones, las competencias y el mercado," Redu. Revista de Docencia Universitaria 6.2 (2008):1-16. 
Blanchflower, David G., and Richard B. Freeman, eds. Youth employment and joblessness in advanced countries. University of Chicago Press, 2007.

Cabases i Pique, María Angels, M., Agnes Pardell Vea and Alex Seres Cabases. "The Model of Youth Employment in Spain (2013-2016)." Politica y Sociedad 54, no. 3 (2017): 733-755.

Cabasés i Piqué, María Angels, María Jesús Gómez Adillón and Agnès Pardell Veà. "Precariedad y temporalidad, principales características del empleo juvenil en España.” Revista del Ministerio de Empleo y Seguridad Social 126 (2016): 3152.

Choudhry, Misbah Tanveer, Enrico Marelli and Marcello Signorelli. "Youth unemployment rate and impact of financial crises." International journal of manpower 33.1 (2012): 76-95.

Clark, Kim B and Lawrence H. Summers. "The Dynamics of Youth Unemployment." In The Youth Labour Market Problem: Its Nature, Causes, and Consequences A National Bureau of Economics Research Conference Report, edited by Richard B. Freeman and David A. Wise, 199 - 234. Chicago and London: The University of Chicago Press, 1982.

Dietrich, Hans. "Youth unemployment in Europe." Theoretical considerations and empirical findings. Available at: library. fes. de/pdf-files/id/ipa/09227. pdf. Last access 16.7 (2012): 2012.

Escudero, Juan María, María T. González and María J. Rodríguez. "La mejora equitativa de la educación y la formación del profesorado." REMIE: Multidisciplinary Journal of Educational Research 3.3 (2013): 206-234.

Esteban, Manuel and Juan Sáez. "Las profesiones, las competencias y el mercado." Redu. Revista de Docencia Universitaria 6.2 (2008): 1-16.

Estrada García, Alex. "Estilos de aprendizaje y rendimiento académico." Revista Boletín Redipe 7.7 (2018): 218-228.

European Commission. Directorate- General for Employment, Social Affairs and Inclusion. Employment and social developments in Europe 2013, Bruxelles. (2013)

European Commission. Directorate-General for Employment. Employment and social developments in Europe 2011. Vol. 1. Publications Office of the European Union, 2012.

Eurostat. Participation of young people in education and the labour market. 2016

- People at risk of poverty or social exclusion (Europe 2020 Strategy). Brussels, 2018.

Eurostat Statistic Explained (February 2019), https://ec.europa.eu/eurostat/statisticsexplained/index.php?title=Employment_statistics/es

Foessa, Fundación. VII Informe sobre exclusión social y desarrollo social en España. Madrid: Cáritas Española, 2014. https://www.foessa2014.es/informe/uploaded/ descargas/VII_INFORME.pdf

García-Fuentes, Juan. "Exclusión socio-educativa de los ni-ni: análisis descriptivo de los procesos de transición.” Revista Internacional de Didáctica y Organización Educativa 2.1 (2017). 
Gil Flores, Javier. "Hábitos lectores y competencias básicas en el alumnado de educación secundaria obligatoria." Educación XX1. 14.1, 2011, pp. 117-134

Guamán Hernández, Adoración. "De la estabilidad en el empleo a la precariedad laboral por la vía de la contratación temporal: la inserción de los jóvenes en el mercado de trabajo como paradigma del trabajo precario." (2013).

INE. Instituto Nacional de Estadística. Encuesta de Población Activa (EPA). Cuarto trimestre 2019. Madrid, Published January 28, 2020, in https://www.ine.es/daco/ daco42/daco4211/epa0419.pdf

Jimeno, Juan F and Diego Rodriguez-Palenzuela. "Youth unemployment in the OECD: demographic shifts, labour market institutions, and macroeconomic shocks." (2002).

Jolonch, Anna. Exclusió social: dels marges al cor de la societat. Fundació Lluís Carulla, 2008.

Lasheras, Rubén and Begoña Pérez Eransus. "Jóvenes, vulnerabilidades y exclusión social: impacto de la crisis y debilidades del sistema de protección social." Zerbitzuan: Gizarte zerbitzuetarako aldizkaria $=$ Revista de servicios sociales 57 (2014): 137-157.

Longás, Jordi and Jordi Riera. "Fracaso escolar y tránsito hacia la vida adulta. Razones y propuestas para apoyar la transición de la escuela al trabajo." Educación Social. 49 (2007): 147-162.

Longás, Jordi, Irene Cussó, Roser de Querol and Jordi Riera. “Análisis de factores de apoyo a trayectorias de éxito escolar en la enseñanza secundaria en contextos de pobreza y vulnerabilidad social en España. Un estudio de casos múltiples." REXE. Revista de Estudios y Experiencias en Educación 15.28 (2016): 107-127.

Marelli, Enrico and Signorelli Marcello. "Young people in crisis times: Comparative evidence and policies." CESifo Forum. Vol. 18. No. 2. München: ifo InstitutLeibniz-Institut für Wirtschaftsforschung an der Universität München, 2017.

Meltzer, Ariella, Kristy Muir and Lyn Craig. "The role of trusted adults in young people's social and economic lives." Youth \& Society 50.5 (2018): 575-592.

Ministerio de Educación, Cultura y Deporte. "Sistema Estatal de Indicadores de la Educación 2017.” (2017).

MacDonald, Robert. "Disconnected youth? Social exclusion, the 'underclass'\& economic marginality.” Social Work \& Society 6.2 (2008): 236-248.

Moreno López, Roberto. Formación e inserción sociolaboral en Educación Social. Vol. 27. Nau Llibres, 2018.

Moreno López, Roberto, Rosa Marí Ytarte and Beatriz Esteban Ramiro. "Labour market, education and the specific youth programs: study of perception in Toledo-Spain." International Journal of Adolescence and Youth (2019): 1-17.

Observatorio de Innovación en el Empleo, Informe EOI sobre jóvenes y mercado laboral: El camino del aula a la empresa. Spain: OIE, 2014. https://oie.es/wpcontent/uploads/2015/07/oie_estudio_2017.pdf

OECD. Education at a Glance 2016 OECD Indicators. OECD Publishing, 2016.

Planas, Jordi. "La relación entre educación y empleo en Europa." Papers: revista de sociologia 96.4 (2011): 1047-1073. 
Programa de Naciones Unidas para el Desarrollo Informe sobre Desarrollo Humano 2014. Sostener el progreso humano: reducir vulnerabilidades y construir resiliencia, Nueva York, 2014.

Ruiz, María Auxiliadora, Miguel Angel Sancho, and Mercedes de Esteban.Indicadores comentados sobre el estado del sistema educativo español: 2017. Fundación Ramón Areces, 2016.

Sarasa, Sebastián and Albert Sales. "Itinerarios y factores de exclusión social.” Barcelona: Fundación La Caixa (2009).

Secretaria de Trabajo, Migraciones y Seguridad Social. "Informe jóvenes y mercado de trabajo" junio-2018.http://www.mitramiss.gob.es/es/sec_trabajo/analisismercado-trabajo/jovenes/numeros/2018/junio_2018.pdf.

Scarpetta, Stefano, Anne Sonnet, and Thomas Manfredi. "Rising youth unemployment during the crisis." (2010).

Tarabini-Castellani, Aina. “QQué se esconde bajo las apariencias?” Cuadernos de pedagogía 454 (2015): 42-43.

United Nations Development Programme. "UNDP youth strategy 2014-2017." (2014). https://www.undp.org/content/undp/en/home/librarypage/democraticgovernance/youthstrategy.html

Vasile, Valentina and Liviu Vasile. "Youths on labour market.Features. Particularities. Pro-mobility factors for graduates. Elements of a balanced policy for labour migration." Romanian Journal of Economics 32.1 (2011): 41.

Vasile, Valentina and Irina Anghel. "The educational level as a risk factor for youth exclusion from the labour market." Procedia Economics and Finance 22.2015 (2015): 64-71.

Verd Pericàs, Joan Miquel, Lídia Yepes and Mattia Vacchiano. "Trayectorias laborales y capital social en la población joven: elementos para analizar la precariedad laboral juvenil más allá de los grandes focos." Anuario IET de trabajo y relaciones laborales 3 (2016): 0144-158.

\section{About the authors:}

ROBERTO MORENO LÓPEZ (roberto.moreno@uclm.es) is an associate professor at the University of Castilla-La Mancha (UCLM) in the Department of Pedagogy. $\mathrm{He}$ is a teacher and coordinator of the Degree in Social Education at the Faculty of Social Sciences in Talavera de la Reina (Toledo). Doctor in Humanities and Education from UCLM. the same university. He obtained his Degree in Social Education and a master's degree in Research in Applied Psychology, Expert in Development Cooperation, Specialist in Human Rights and Culture of Peace. (UCLM) He is a member of the GIES - Research Group on Education and Society of the UCLM and its main lines of research focus on inequalities and the social inclusion of vulnerable groups. Furthermore, he is a social educator in the third sector in Spain. 
BEATRIZ ESTEBAN RAMIRO (beatriz.esteban@uclm.es) is an Associate Professor at the University of Castilla-La Mancha (UCLM) in the Department of Labor Law and Social Work. She is a personal teacher and researcher in the Degree of Social Work, at the Faculty of Social Sciences in Talavera de la Reina (Toledo). Currently, she is a $\mathrm{PhD}$ student at the same university. His studies focus on the comparative analysis of minimum incomes in the European context, focusing on social policies for socially vulnerable and poor people. She earned her undergraduate degree in Social Work and she's entitled master's in research in Applied Psychology and Expert in Equality: gender perspective applied to social intervention. (UCLM). Her main lines of research focused on social and gender inequalities, applying a perspective to social action. In addition, she is a social worker, their career development is linked to public-private agencies.

RUT BARRANCO BARROSO (rut.barranco@uclm.es) is an associate professor in Social Education at the Social Sciences College of Talavera de la Reina at the University of Castilla- La Mancha (Spain) and is a member of the Research Group in Education and Society from the same university. She got the Diploma of Advanced Studies in Education and Social Change some years ago and also completed the master's in applied Anthropology at the University of Castilla-La Mancha. She studied Pedagogy and Psychopedagogy and graduated in Social Education and Teaching at the Pontifical University of Salamanca. At the moment, she combines her work as a counselor and head of studies at an Adult Education Center with teaching and research at UCLM 


\title{
Young people's uncertainty about the future: Education system, training, and transition to employment in Spain
}

\author{
Roberto Moreno López, Beatriz Esteban Ramiro, and Rut Barranco Barroso
}

doi: http://dx.doi.org/10.18543/tjhe-7(2)-2020pp67-89

\section{Copyright}

Copyright for this article is retained by the Publisher. It is an Open Access material that is free for full online access, download, storage, distribution, and or reuse in any medium only for noncommercial purposes and in compliance with any applicable copyright legislation, without prior permission from the Publisher or the author(s). In any case, proper acknowledgement of the original publication source must be made and any changes to the original work must be indicated clearly and in a manner that does not suggest the author's and or Publisher's endorsement whatsoever. Any other use of its content in any medium or format, now known or developed in the future, requires prior written permission of the copyright holder. 